\title{
Incidence and transmission patterns of tuberculosis among indigenous populations in Brazil
}

\author{
Eunice Atsuko Cunha ${ }^{1 /}{ }^{+}$, Lucilaine Ferrazoli ${ }^{2}$, Lee W Riley ${ }^{3}$, Paulo Cesar Basta ${ }^{4}$, \\ Michael Robert Honer ${ }^{5}$, Rosalia Maia ${ }^{6}$, Izaias Pereira da Costa ${ }^{7}$
}

\begin{abstract}
${ }^{1}$ Seção de Micobacteriologia, Laboratório Central de Saúde Pública de Mato Grosso do Sul, Campo Grande, MS, Brasil ${ }^{2}$ Núcleo de Tuberculose e Micobacteriose, Instituto Adolfo Lutz, São Paulo, SP, Brasil ${ }^{3}$ Division of Infectious Diseases \& Vaccinology, School of Public Health, University of California, Berkeley, CA, USA ${ }^{4}$ Escola Nacional de Saúde Pública-Fiocruz, Rio de Janeiro, RJ, Brasil ${ }^{5}$ Universidade Católica Dom Bosco, Campo Grande, MS, Brasil ${ }^{6}$ Programa Nacional de Controle da Tuberculose, Ministério da Saúde, Brasilia, DF, Brasil ${ }^{7}$ Faculdade de Medicina, Universidade Federal de Mato Grosso do Sul, Campo Grande, MS, Brasil
\end{abstract}

Approximately 10\% of the Brazilian indigenous population lives in the state of Mato Grosso do Sul (MS), where a large number of new cases of tuberculosis (TB) are reported. This study was conducted to assess TB occurrence, transmission and the utility of TB diagnosis based on the Ogawa-Kudoh $(O-K)$ culture method in this remote population. The incidence of TB was estimated by a retrospective review of the surveillance data maintained by the Notifiable Diseases Surveillance System for the study region. The TB transmission pattern among indigenous people was assessed by genotyping Mycobacterium tuberculosis isolates using the IS6110 restriction fragment length polymorphism (RFLP) technique. Of the 3,093 cases identified from 1999-2001, 610 ( 20\%) were indigenous patients (average incidence: 377/100,000/year). The use of the O-K culture method increased the number of diagnosed cases by $34.1 \%$. Of the genotyped isolates from 52 indigenous patients, 33 (63.5\%) belonged to cluster RFLP patterns, indicating recently transmitted TB. These results demonstrate high, on-going TB transmission rates among the indigenous people of MS and indicate that new efforts are needed to disrupt these current transmissions.

Key words: tuberculosis - genotyping - microbiology - molecular epidemiology - South American indigenous people

In Brazil, the incidence and mortality from tuberculosis (TB) decreased by $20 \%$ and $30 \%$ from 1990 2010, respectively. However, TB control remains an important challenge in the country (Barreto et al. 2011, Oliveira et al. 2013).

One particular challenge is the control of TB among remote populations, such as the indigenous populations of Brazil. The high incidence and mortality resulting from $\mathrm{TB}$, initially described in the mid-20th century among indigenous people (Costa 1987), has remained unchanged (Marques \& Cunha 2003, Basta et al. 2006, 2010, Bóia et al. 2009, Marques et al. 2010, Croda et al. 2012, Rios et al. 2013, Sacchi et al. 2013). It is not known if the high incidence of TB represents a high rate of current transmission or reactivation of previous TB infections.

In the 1960s, in the state of Mato Grosso do Sul (MS), Cauiá Evangelical Mission built a new hospital [Porta da Esperança Hospital (PEH)] in the municipality of Dourados to provide healthcare service for its indigenous patients. Approximately 30 years later, the local healthcare authorities initiated a program to expand case detection and TB diagnostic tests to improve treatment

doi: 10.1590/0074-0276130082

Financial support: DAHW

+ Corresponding author: euniceatsuko@uol.com.br

Received 11 February 2013

Accepted 5 September 2013 among the indigenous people. As part of this program, the Ogawa-Kudoh $(\mathrm{O}-\mathrm{K})$ method to culture sputum was introduced with support from the Central Laboratory of Public Health of Mato Grosso do Sul (LACEN-MS).

The purpose of this study was to describe TB incidence and transmission patterns among indigenous people in MS during the period ranging from 1999-2001 and to assess the improvement in TB case detection based on the $\mathrm{O}-\mathrm{K}$ culture method.

MS had a population of $2,078,072$ people in 2000 , of which $53,900(2.6 \%)$ belonged to indigenous groups (IBGE 2011). During the study period, the Special Indigenous Health District of Mato Grosso do Sul (DSEIMS) provided healthcare assistance to individuals of the Guarani-Kaoiwá, Terena, Kadiwéu, Kinikinawa and Guató ethnic groups. The DSEI-MS was organised into 13 Primary Care Units covering 29 municipalities, which included over 15,000 households scattered across 75 villages.

At the time of the study, PEH conducted clinical assessment and collection of biological samples for all indigenous patients suspected to have TB. The O-K culture method was implemented in September 1999.

Reported patient data were reviewed from the Notifiable Diseases Surveillance System (SINAN) for MS and from reports available at PEH covering the period from 1999-2001.

All indigenous patients who started TB treatment and were reported by the SINAN were included in the analysis to estimate incidence. Assessment of improvements in diagnosis after the introduction of the O-K culture method was based on guidelines of the Pan-Amer- 
ican Health Organization (OMS/OPAS 2008) and on a proposal by McCarthy et al. (2008).

At the PEH laboratory, the sputum specimens were examined by microscopy (Ziehl-Neelsen staining) and were cultured after decontamination by the swab method with $4 \%$ sodium hydroxide and inoculated in O-K eggbased medium (WHO 1998). Once seeded, cultures were sent to LACEN-MS where they were incubated at $37^{\circ} \mathrm{C}$. The results (negative or positive) were reported within 60 days of incubation. A drug susceptibility test (DST) was performed using Canetti's proportion method for isoniazid, rifampicin, pyrazinamide, ethambutol and streptomycin (Canetti et al. 1963).

Only cases in which Mycobacterium tuberculosis was isolated from culture were included in the analysis of transmission patterns. M. tuberculosis isolates were genotyped according to a standardised IS6110 restriction fragment length polymorphism (RFLP) method described by van Embden et al. (1993). RFLP-IS6110 gel electrophoretic banding patterns were analysed using the BioNumerics software, version 5.0 (Applied Maths, Kortrijk, Belgium). Patterns were compared according to pair groups based on non-weighted arithmetic averages and Dice coefficients. Two or more isolates were defined as belonging to a cluster when their IS6110 electrophoretic band patterns were indistinguishable. These strains were considered to have been isolated from TB patients who acquired the infection recently. Strains with profiles in which the similarity index was equal to or higher than $65 \%$ were grouped as belonging to a family.
This study was part of a wider research project titled Epidemiological Assessment and Operationalisation to Diagnose Tuberculosis in the Guarani-Kaiowá Population in the state of Mato Grosso do Sul. This project was approved by the Research Ethical Committee of the Federal University of Mato Grosso do Sul and by the National Commission of Research Ethics (126/2001).

According to the data available from SINAN, 3,093 TB cases were reported from MS from 1999-2001, of which $610(\sim 20 \%)$ occurred among indigenous individuals. Of this total, $562(92.1 \%), 33(5.4 \%)$ and $15(2.5 \%)$ were cases of pulmonary, extrapulmonary and mixedform disease in indigenous patients vs. 2,108 (85.3\%), $319(12.9 \%)$ and $43(1.7 \%)$ in non-indigenous patients, respectively. Most individuals (63.4\%) were male. The mean age of indigenous patients was 25 years vs. 40 years among non-indigenous individuals $(\mathrm{p}<0.001)$. The mean annual incidence, based on data for the year 2000 (median of the period), was $424.9 / 100,000$ for the indigenous population vs. 38.1/100,000 for non-indigenous residents (48.1/100,000 residents for the state as a whole).

More than half of the cases among indigenous individuals were reported from the Primary Care Unit of Dourados, which reported an average incidence of 1,102 cases per 100,000 inhabitants. The Amambai, Antônio João and Caarapó Primary Care Units had 540, 474 and 288 cases per 100,000 inhabitants, respectively (Table I). In the study period, 797 patients were evaluated and 321 TB cases were diagnosed at PEH (52\% of all indigenous notified cases). For diagnostic investigation, 1,539

\section{TABLE I}

Population, number of tuberculosis cases (all forms) and incidence rate per 100,000 residents, by Primary Care Unit of the state of Mato Grosso do Sul (MS), Brazil, 1999-2001 ${ }^{a}$

\begin{tabular}{|c|c|c|c|c|c|c|c|c|c|c|c|c|}
\hline \multirow[b]{2}{*}{ Primary Care Unit } & \multicolumn{3}{|c|}{$\begin{array}{l}\text { Population } \\
\text { (n) }\end{array}$} & \multirow[b]{2}{*}{ Total } & \multicolumn{4}{|c|}{$\begin{array}{c}\text { Cases } \\
\text { (n) }\end{array}$} & \multicolumn{4}{|c|}{ Incidence } \\
\hline & 1999 & 2000 & 2001 & & 1999 & 2000 & 2001 & Total & 1999 & 2000 & 2001 & Average \\
\hline Amambai & 8,519 & 9,009 & 9,463 & 26,991 & 63 & 49 & 34 & 146 & 739.5 & 543.9 & 359.3 & 540.9 \\
\hline Antonio João & 1,400 & 1,480 & 1,546 & 4,426 & 7 & 5 & 9 & 21 & 500.0 & 337.8 & 582.1 & 474.5 \\
\hline Aquidauna & 6,545 & 6,711 & 6,909 & 20,165 & 3 & 3 & 2 & 8 & 45.8 & 44.7 & 28.9 & 39.7 \\
\hline Bodoquena & 839 & 867 & 902 & 2,608 & 1 & 0 & 0 & 1 & 119.2 & 0.0 & 0.0 & 38.3 \\
\hline Bonito & 500 & 524 & 540 & 1,564 & 2 & 0 & 0 & 2 & 400.0 & 0.0 & 0.0 & 127.9 \\
\hline Caarapó & 4,491 & 4,742 & 4,962 & 14,195 & 16 & 16 & 9 & 41 & 356.3 & 337.4 & 181.4 & 288.8 \\
\hline Campo Grande & 3,055 & 3,157 & 3,241 & 9,453 & 1 & 2 & 0 & 3 & 32.7 & 63.4 & 0.0 & 31.7 \\
\hline Dourados & 9,222 & 9,741 & 10,167 & 29,130 & 97 & 136 & 88 & 321 & 1.051 .8 & 1.396 .2 & 865.5 & 1.102 .0 \\
\hline Iguatemi & 3,984 & 4,178 & 4,369 & 12,531 & 7 & 8 & 6 & 21 & 175.7 & 191.5 & 137.3 & 167.6 \\
\hline Miranda & 5,796 & 5,956 & 6,134 & 17,886 & 14 & 5 & 13 & 32 & 241.5 & 83.9 & 211.9 & 178.9 \\
\hline Paranhos & 2,890 & 3,048 & 3,203 & 9,141 & 4 & 2 & 1 & 7 & 138.4 & 65.6 & 31.2 & 76.6 \\
\hline Sidrolândia & 2,593 & 2,672 & 2,773 & 8,038 & 2 & 1 & 0 & 3 & 77.1 & 37.4 & 0.0 & 37.3 \\
\hline Tacuru & 2,523 & 2,654 & 2,753 & 7,930 & 5 & 2 & 6 & 13 & 198.2 & 75.4 & 217.9 & 163.9 \\
\hline Total & 52,357 & 54,739 & 56,962 & 164,058 & 222 & 229 & 168 & 620 & 424.0 & 418.3 & 294.9 & 377.3 \\
\hline
\end{tabular}

$a$ : data only to indigenous population who was assisted by primary health units. Source: Notifiable Diseases Surveillance System/Secretary of Health-MS and Information System of Care for Indigenous Health/National Health Foundation. 
sputum smears and 1,441 cultures were performed, of which 126 samples tested positive for Mycobacterium. Mycobacterium organisms were identified in 126 specimens from 99 patients. Four of the 126 samples were Mycobacterium spp other than M. tuberculosis.

Of the 99 culture-positive cases, 43 were smear-negative and 55 were smear-positive. In one of the positive culture samples, the smear test was not performed. Of the 1,441 cultures performed, $16(1.1 \%)$ were smearpositive and culture-negative, nine $(0.6 \%)$ were smearpositive and culture-contaminated and $78(5.4 \%)$ were contaminated. The culture detection method increased the TB diagnosis frequency by $34.1 \%$. Of the $90 \mathrm{M}$. tuberculosis isolates subjected to DST, all were sensitive to the five drugs tested.

RFLP-IS6110 genotyping was performed on 52 (52.2\%) M. tuberculosis isolates from 99 patients. The number of IS6110 copies (bands) ranged from four-17 among these isolates. Two isolates contained four bands in the same position, suggesting contamination by two strains and were excluded from the analysis (Figure).

Of the genotyped isolates, 52 were isolated from indigenous patients, while seven were obtained from non-indigenous patients. Thirty-three $(63.5 \%)$ belonged to cluster profiles A, B, B1, D, E, G, G1, G4 and G5. The number of strains per each cluster ranged from twoeight. Twenty-nine strains were distributed into only three families (A, B, G), totalling nearly $56 \%$ of all analysed strains (Table II). There were no differences in the mean age or gender according to cluster vs. non-cluster RFLP patterns.

A noteworthy feature was that in the village of Bororó, four strains of the B family and five strains of the $\mathrm{G}$ family were identified. In the village of Jaguapiru, two group D strains were isolated and in the village of Itaum, two G1 strains were found. One group A and two group E strains were identified in the village of Amambai. These findings allowed an epidemiologic connection to be established for 16 (30.8\% of 52) indigenous individuals (Table II). The number of available strains from non-indigenous patients that were genotyped $(\mathrm{n}=$ 7) was too small to make any conclusions about transmission patterns.

This investigation confirmed that $\mathrm{TB}$ is a major healthcare concern for the indigenous populations of MS and demonstrated that the incidence during the study period was far greater than the national and regional averages or the incidence among non-indigenous people (Croda et al. 2012, Oliveira et al. 2013). Based on genotyping test results, a high rate of recent transmission appears to be occurring in indigenous subjects.

The implementation of the swab method with inoculation in $\mathrm{O}-\mathrm{K}$ medium increased case detection by $34.1 \%$ compared to smear microscopy alone.

The use of this method for diagnosing TB in an indigenous population in Brazil for the first time was based on its ease of use because centrifugation is not required and the risk of contamination posed to healthcare professionals is lower. Furthermore, the method ensures incubation for up to 20 days after seeding, without com- promising performance (Sushemihl et al. 1993, Honscha et al. 2008, Jaspe et al. 2009, Rivas et al. 2010, Palaci et al. 2013).

The high level of genotype similarity among $M . t u-$ berculosis strains within indigenous villages in Amambai and Dourados differs from the patterns described for other locations in Brazil (Fandinho et al. 2000, Ferrazoli et al. 2000, Suffys et al. 2000, Valim et al. 2006) and other countries (Frieden et al. 1996, Ferdinand et al. 2003, $\mathrm{Hu}$ et al. 2011), although these studies have focused on multidrug-resistant strains.

Comparable levels of similarity between strains have been reported among the Inuit in Canada (76\%) (Nguyen et al. 2003) and the Waarao in Venezuela (78\%) (Maes et al. 2008), in whose indigenous communities TB prevalence is higher than among the general population.

One limitation of this study is that due to inadequate storage of the isolates (frozen to $-20^{\circ} \mathrm{C}$ ), it was not possible to perform genetic analyses on all $M$. tuberculosis isolates. It is possible that other strain types circulate in the region, but that they were not identified in this study. In addition, not all reported cases used to estimate the TB incidence were confirmed by bacteriological examination.

As a result of these findings, the Dourados and Amambai Primary Care Units improved their TB control activities to interrupt TB transmission. These activities included early and high-quality diagnosis (using O-K medium), timely treatment (under dots strategy) and expanded close contact tracing. Moreover, after 2001, a preventive treatment program for latent TB infections was introduced into these communities, targeting children less than 10 years of age.

As noted by Croda et al. (2012), the above activities had a positive impact on TB control in recent years. The authors analysed not only factors predictive of failure in treatment, but also mortality in Dourados from 20022008. The authors concluded that there was a $90 \%$ reduction in non-completion of TB treatment among the indigenous population after dots implementation. Interestingly, the non-indigenous TB patients had 4.5 times higher mortality than the indigenous TB patients. Furthermore, Marques et al. (2010) and Santos et al. (2013) showed that the incidence of new TB cases in children less than 10 years of age decreased by approximately $40 \%$ between $2000-2006$.

However, given the precarious living conditions of the indigenous populations (marked by poverty, hunger, malnutrition, anaemia, high parasite infestation and high infant mortality rates), combined with the confinement of these population to small areas (reservations, whose boundaries have been defined and approved by the federal government), TB incidence rates remain unacceptably high at approximately 200 cases per 100,000 inhabitants. Here, we have shown that the O-K culture method is simple, practical and inexpensive and that it increases case detection rates among this remote population. Nevertheless, new concerted efforts and investments are required to better characterise factors that contribute to the current high transmission frequencies among indigenous peoples from MS. 
$\begin{array}{llll}40 & 60 & 80 & 100\end{array}$
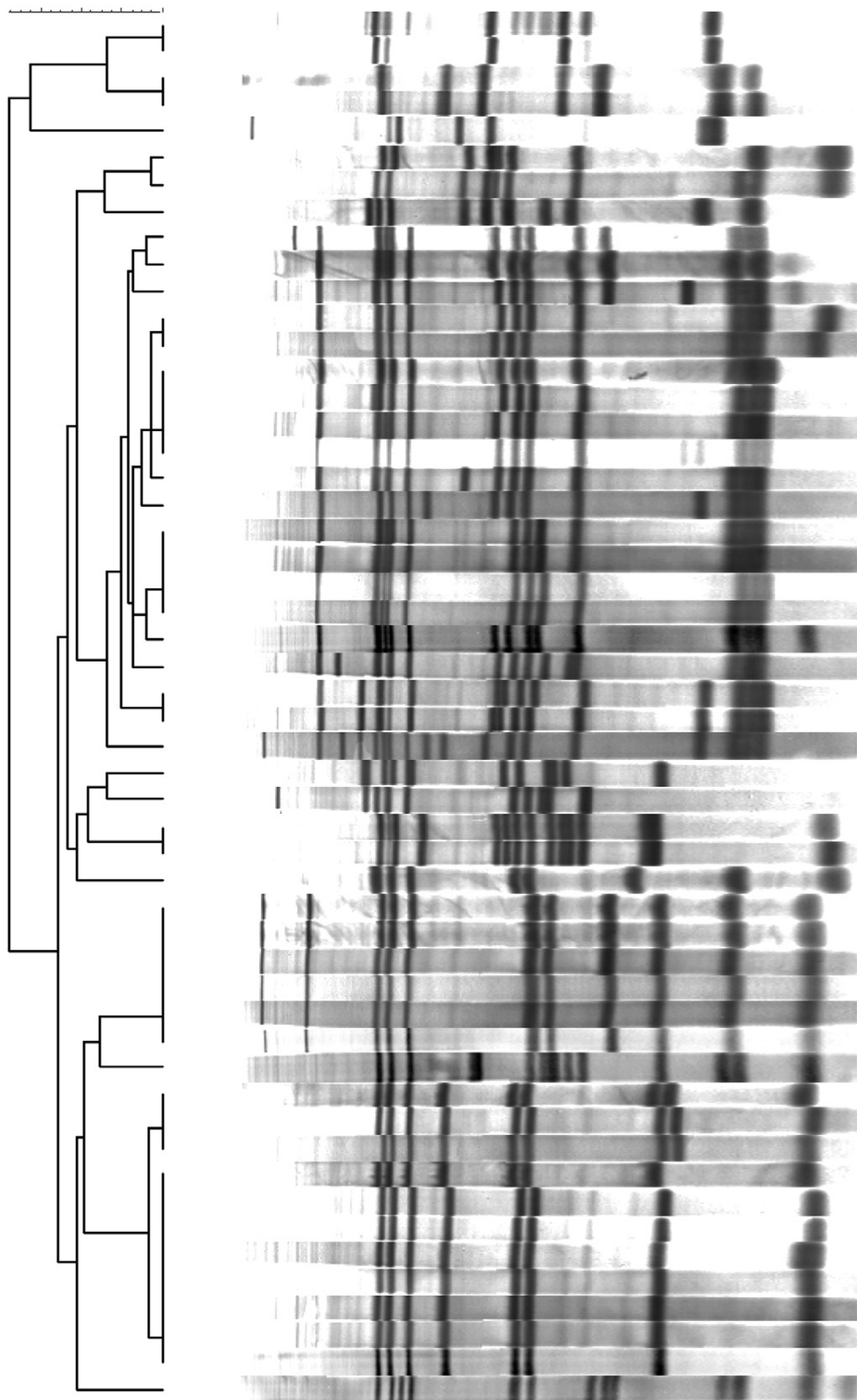

$4 B^{*}$

$4 \mathrm{~B}^{*}$

D

UP*

$\mathrm{J} *$

$\mathrm{J} 1^{*}$

$U P^{*}$

G11 *

G12*

G8*

G5

G5

G4

G4

G4

G4

$\mathrm{G6}^{*}$

$\mathrm{G} 7^{*}$

G

G

G

G

G3*

$\mathrm{G} 2^{*}$

G1

G1

G10*

$U^{*}$

$F^{*}$

E

E

$U P^{*}$

A

A

A

A

A

A

UP*

B1

B1

B1

B

B

B

B

B

B

B

B

UP*

Restriction fragment length polymorphism (RFLP)-IS6110 pattern of 52 Mycobacterium tuberculosis isolates obtained from indigenous individuals from the state of Mato Grosso do Sul, Brazil (1999-2001). Patterns are organised by similarity according to the dendrogram to the left. Bands were aligned adopting the MT 14323 strain as the reference, using BioNumerics software, version 5.0 (Applied Maths, Kortrijk, Belgium). Asterisk means non-cluster pattern. 


\section{TABLE II}

Characteristics of Mycobacterium tuberculosis strains by village according to cluster and non-cluster restriction fragment length polymorphism (RFLP) patterns, state of Mato Grosso do Sul, Brazil, 1999-2001

\begin{tabular}{|c|c|c|c|c|c|c|c|c|c|c|c|c|c|c|c|c|c|c|c|c|c|c|c|}
\hline \multirow[b]{2}{*}{ Villages } & \multirow{2}{*}{$\begin{array}{l}\text { M. tuberculosis } \\
\text { isolates } \\
\text { (n) }\end{array}$} & \multicolumn{9}{|c|}{ RFLP cluster patterns } & \multicolumn{13}{|c|}{ RFLP non-cluster patterns } \\
\hline & & A & $\mathrm{B}$ & B1 & $\mathrm{D}$ & $\mathrm{E}$ & G & G1 & G4 & G5 & 4B & $\mathrm{F}$ & G11 & G12 & $\mathrm{G} 2$ & G3 & G6 & G7 & G8 & G10 & $\mathrm{J}$ & $\mathrm{J} 1$ & $\mathrm{UP}^{a}$ \\
\hline Amambai & 9 & $1^{b}$ & - & - & - & $2^{b}$ & - & - & 1 & - & 2 & 1 & 1 & - & - & - & - & - & - & - & 1 & - & - \\
\hline Bororó & 13 & 1 & $3^{b}$ & $1^{b}$ & - & - & $3^{b}$ & - & 1 & 1 & - & - & - & - & 1 & - & - & 1 & - & 1 & - & - & - \\
\hline Caarapó & 3 & - & 1 & - & - & - & 1 & - & - & 1 & - & - & - & - & - & - & - & - & - & - & - & - & - \\
\hline Dourados & 1 & - & - & - & - & - & - & - & 1 & - & - & - & - & - & - & - & - & - & - & - & - & - & - \\
\hline Guaimbé & 2 & - & 1 & - & - & - & - & - & - & - & - & - & - & - & - & - & - & - & - & - & - & - & 1 \\
\hline Guassuty & 1 & - & - & - & - & - & - & - & - & - & - & - & - & - & - & 1 & - & - & - & - & - & - & - \\
\hline Itaum & 2 & - & - & - & - & - & - & $2^{b}$ & - & - & - & - & - & - & - & - & - & - & - & - & - & - & - \\
\hline Jaguapirú & 7 & 1 & 1 & - & $2^{b}$ & - & - & - & - & - & - & - & - & - & - & - & - & - & 1 & - & - & - & 2 \\
\hline Jarara & 1 & 1 & - & - & - & - & - & - & - & - & - & - & - & - & - & - & - & - & - & - & - & - & - \\
\hline Limão Verde & 3 & $2^{b}$ & - & 1 & - & - & - & - & - & - & - & - & - & - & - & - & - & - & - & - & - & - & - \\
\hline Miranda & 1 & - & - & - & - & - & - & - & - & - & - & - & - & - & - & - & - & - & - & - & - & - & 1 \\
\hline Passarinho & 1 & - & - & - & - & - & - & - & - & - & - & - & - & - & - & - & - & - & - & - & - & - & 1 \\
\hline Pirakuá & 1 & - & - & - & - & - & - & - & - & - & - & - & - & - & - & - & 1 & - & - & - & - & - & - \\
\hline Porto Lindo & 2 & - & 1 & - & - & - & - & - & - & - & - & - & - & - & - & - & - & - & - & - & - & - & 1 \\
\hline Sardinha & 1 & - & 1 & - & - & - & - & - & - & - & - & - & - & - & - & - & - & - & - & - & - & - & - \\
\hline Taquaperi & 4 & - & - & 1 & - & - & - & - & 1 & - & - & - & - & 1 & - & - & - & - & - & - & - & 1 & - \\
\hline Total & 52 & 6 & 8 & 3 & 2 & 2 & 4 & 2 & 4 & 2 & 2 & 1 & 1 & 1 & 1 & 1 & 1 & 1 & 1 & 1 & 1 & 1 & 6 \\
\hline
\end{tabular}

$a$ : unique pattern; $b$ : individuals for whom epidemiological connection was established.

\section{ACKNOWLEDGEMENTS}

To the team of the DSEI-MS, to Roselene Lopes de Oliveira and Nelson Carmelo Olazar, to Wanderley Guenka, DESAI/ FUNASA, Brasília, to the Missão Caiuá Hospital team, for granted access to patients and their charts, to former member Irene Castilho, and to Aleuyr de Oliveira Lima, LACEN-MS.

\section{REFERENCES}

Barreto ML, Teixeira MG, Bastos FIP, Ximenes RAA, Barata RB, Rodrigues LC 2011. Successes and failures in the control of infectious diseases in Brazil: social and environmental context, policies, interventions and research needs. Lancet 377: 1877-1889.

Basta PC, Coimbra Jr CEA, Camacho LAB, Santos RV 2006. Risk of tuberculosis infection in an indigenous population from Amazônia, Brazil. Int J Tuberc Lung Dis 10: 1354-1359.

Basta PC, Coimbra Jr CEA, Welch JR, Alves LCC, Santos RV, Camacho LAB 2010. Tuberculosis among the Xavante Indians of the Brazilian Amazon: an epidemiological and ethnographic assessment. Ann Hum Biol 37: 643-657.

Bóia MN, Carvalho-Costa FA, Sodré FC, Porras-Pedroza BE, Faria EC, Magalhães GAP, da Silva IM 2009. Tuberculose e parasitismo intestinal em população indígena na Amazônia brasileira. Rev Saude Publica 43: 176-178.

Canetti G, Rist N, Grosset J 1963. Mesure de la sensibilité du bacille tuberculeux aux drogues antibacillairespar la méthode des proportions. Méthodologie, critères de résistance, résultats, interprétation. Rev Tuberc Pneumol (Paris) 27: 217-272.

Costa DC 1987. Política indigenista e assistência à saúde. Noel Nutels e o Serviço de Unidades Sanitárias Aéreas. Cad Saude Publica 4: $388-401$.
Croda MG, Trajber Z, Lima RC, Croda J 2012. Tuberculosis control in a highly endemic indigenous community in Brazil. Trans $R$ Soc Trop Med Hyg 106: 223-229.

Fandinho FCO, Kritiski AL, Hofer C, Conde HR, Ferreira RMC, Saad MH, Silva MG, Riley LW, Fonseca LS 2000. RFLP patterns and risk factors for recent tuberculosis transmission among hospitalized tuberculosis patients in Rio de Janeiro, Brazil. Trans $R$ Soc Trop Med Hyg 94: 271-275.

Ferdinand S, Sola C, Verdol B, Legrand E, Goh KS, Berchel M, Aubéry A, Timothée M, Joseph P, Pape JW, Rastogi N 2003. Molecular characterization and drug resistance patterns of strains of Mycobacterium tuberculosis isolated from patients in an AIDS Counseling Center in Port-au-Prince, Haiti: a 1-year study. J Clin Microbiol 41: 694-702.

Ferrazoli L, Palaci M, Marques LRM, Jamal LF, Afiune JB, Chimara E, Martins MC, Silva Telles MA, Oliveira CA, Palhares MC, Spada DT, Riley LW 2000. Transmission of tuberculosis in an endemic urban setting in Brazil. Int J Tuberc Lung Dis 4: 1-8.

Frieden TR, Woodley CL, Crawford JT, Lew D, Dooley SM 1996. The molecular epidemiology of tuberculosis in New York City: the importance of nosocomial transmission and laboratory error. Int J Tuber Lung Dis 77: 407-413.

Honscha G, von Groll A, Valença M, Ramos DF, Sanchotene K, Scaini CJ, Ribeiro MO, da Silva PEA 2008. The laboratory as tool to qualify tuberculosis diagnosis. Int J Tuberc Lung Dis 12: 218-220.

Hu Y, Mathema B, Jiang W, Kreiswirt B, Weibing W, Xu B 2011. Transmission pattern of drug-resistant tuberculosis and implication for tuberculosis control in eastern rural China. PLOS ONE 6: e19548. 
IBGE - Instituto Brasileiro de Geografia e Estatística 2011. Sistema IBGE de Recuperação Automática [cited 2011 August 8]. Available from: sidra.ibge.gov.br/bda/tabela/protabl. asp? $=2093 \& \mathrm{z}=\mathrm{cd} \& \mathrm{o}=11 \& \mathrm{i}=\mathrm{P}$

Jaspe RC, Rojas YM, Flores LA, Toro S, Takiff H, Waard JH 2009. Evaluation of the Kudoh swab method for the culturing of Mycobacterium tuberculosis in rural areas. Trop Med Int Health 14: 468-471.

Maes M, Kremer K, van Soolingen D, Takiff H, de Waard JH 2008. 24-Locus MIRU-VNTR genotyping is a useful tool to study the molecular epidemiology of tuberculosis among Warao Amerindians in Venezuela. Tuberculosis (Edinb) 88: 490-494.

Marques AMC, Cunha RV 2003. A medicação assistida e os índices de cura de tuberculose e de abandono de tratamento na população indígena Guaraní-Kaiowá no município de Dourados, Mato Grosso do Sul, Brasil. Cad Saude Publica 19: 405-411.

Marques AMC, Pompilio MA, Santos SC, Garnês SJA, Cunha RV 2010. Tuberculose em indígenas menores de 15 anos no estado de Mato Grosso do Sul. Rev Soc Bras Med Trop 43: 700-704.

McCarthy KD, Metchock B, Kanphukiew A, Monkongdee P, Sinthuwattanawibool C, Tasaneeyapan T, Rienthong S, Ngamlert K, Srisuwanvilai LO, Varma JK 2008. Monitoring the performance of mycobacteriology laboratories: a proposal for standardized indicators. Int J Tuberc Lung Dis 12: 1015-1020.

Nguyen D, Proulx JF, Westley J, Louise T, Dery S, Behr M 2003. Tuberculosis in the Inuit community of Quebec, Canada. Am J Respir Crit Care Med 168: 1353-1357.

Oliveira GP, Torrens AW, Bartholomay P, Barreira D 2013. Tuberculosis in Brazil: last ten years analysis - 2001-2010. Braz J Infect Dis 17: 218-233.

OMS/OPAS - Organización Mundial de la Salud/Organización Panamericana de la Salud 2008. Manual para el diagnóstico bacteriológico de la tuberculosis: normas y guía técnica - Parte II. Cultivo. Available from: paho.org/spanish/ad/dpc/cd/tb-laboratórios-cultivo.pdf

Palaci M, Peres RL, Maia R, Cunha EA, Ribeiro MO, Lecco R, Ribeiro CS, Silva RRF, Vinhas SA, Dietze R, Vianna S, de Morais CG 2013. Contribution of the Ogawa-Kudoh swab culture method to the diagnosis of pulmonary tuberculosis in Brazil. Int $J$ Tuberc Lung Dis 17: 782-786.

Rios DPG, Malacarne J, Alves LCC, Sant'anna CC, Camacho LAB, Basta PC 2013. Tuberculose em indígenas da Amazônia brasileira: estudo epidemiológico na região do Alto Rio Negro. Rev Panam de Salud Publica 33: 22-29.

Rivas C, Coitinho C, Dafond V, Corbo M, Baldjian M 2010. Performance of the Ogawa-Kudoh method for isolation of mycobacteria in a laboratory with large-scale workload. Rev Argent Microbiol 42: 87-90.

Sacchi FP, Croda MG, Estevan AO, Ko AI, Croda J 2013. Sugar cane manufacturing is associated with tuberculosis in an indigenous population in Brazil. Trans R Soc Trop Med Hyg 107: 152-157.

Santos SC, Marques AMC, de Oliveira RL, Cunha RV 2013. Diagnóstico da tuberculose em indígenas menores de quinze anos por meio de um sistema de pontuação em Mato Grosso do Sul. J Bras Pneumol 39: 84-91.

Suffys PN, de Araujo MEI, Rosseti ML, Zaha A, Barroso EW, Barreto AMW, Campos E, van Solingen D, Kremer K, Heersma H, Degrave 2000. Usefulness of IS6110-restriction fragment length polymorphism typing of Brazilian strains of Mycobacterium tuberculosis an comparison with an international fingerprint database. Res Microbiol 151: 343-351.

Sushemihl MAAMM, Ferrazoli L, Ueki SYM, Gimenez RD, Palaci M 1993. Avaliação do método de Ogawa-Kudoh para o cultivo de micobactérias. Rev Bras Patol Clin 29: 51-54.

Valim ARM, Possuelo GL, Cafrune PI, Borges M, Ribeiro MO, Rossetti ML, Zaha A 2006. Evaluation and genotyping of multidrugresistant cases of tuberculosis in southern Brazil. Microb Drug Resist 12: 186-191.

van Embden JDA, Cave MD, Crawford JT, Dale JW, Eisenach KD, Gicquel B, Herman P, Martin C, McAdam R, Schinnick TM, Small PM 1993. Strain identification of Mycobacterium tuberculosis by DNA fingerprint: recommendations for a standardized methodology. J Clin Microbiol 31: 406-409.

WHO - World Health Organization 1998. Laboratory services in tuberculosis control. Part III: culture, WHO, Geneva, 97 pp. 